\title{
DZIAŁALNOŚĆ EDUKACYJNA ARCHIWÓW W KSZTAŁCENIU ARCHIWISTÓW NA UNIWERSYTECIE MIKOŁAJA KOPERNIKA W TORUNIU
}

\section{Słowa kluczowe}

edukacja archiwalna; uniwersyteckie kształcenie archiwistów; toruński ośrodek kształcenia archiwistów; funkcja edukacyjna archiwów; działalność edukacyjna archiwów; edukator archiwalny

\section{Keywords}

archival education; university archival training; Toruń center of archival training; educational function of archives; educational activity of archives; archival educator

\section{Streszczenie}

Artykuł składa się z dwóch części. W pierwszej zwrócono uwagę na funkcję edukacyjną archiwów i profil zawodowy osoby mającej realizować zadania wynikające z tej funkcji, czyli edukatora archiwalnego. Wskazano, iż kompetencje zawodowe eduka-

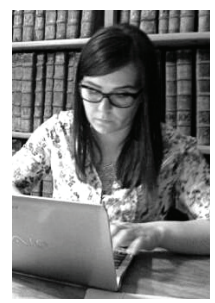

Agnieszka Rosa, doktor nauk humanistycznych, adiunkt w Zakładzie Archiwistyki Uniwersytetu Mikołaja Kopernika w Toruniu. Jej zainteresowania badawcze obejmują: archiwistykę, prace publiczne archiwów, działalność edukacyjną archiwów, problemy edukacji archiwistów, kształcenie użytkowników archiwów, archiwizowanie Internetu, teorię egodokumentu, historię Kujaw. Jest autorką m. in. rozprawy Funkcja edukacyjna archiwów (Warszawa 2012) i współredaktorką serii wydawniczej pt. Toruńskie konfrontacje archiwalne (od 2009 r. ukazały się 4 tomy).E-mail: arosa@umk.pl. 
tora archiwalnego określone zostały w przygotowanym przez Sekcję Edukacji Archiwalnej Stowarzyszenia Archiwistów Polskich i opublikowanym w 2010 r. Modelu kompetencji zawodowych archiwisty $i$ zarządcy dokumentacji w jego części odnoszącej się do poziomu specjalistycznego w zakresie promocji, edukacji i informacji archiwalnej. W drugiej części artykułu przedstawione zostało kształcenie archiwistów na Uniwersytecie Mikołaja Kopernika w Toruniu w zakresie treści i umiejętności odnoszących się do działalności popularyzatorskiej, edukacyjnej i kulturalno-oświatowej archiwów w przeszłości, obecnie i jak ono będzie wyglądać w najbliższej przyszłości.

1D) ziałania edukacyjne i popularyzatorskie podejmowane przez archiwa swoje korzenie mają w wiekach wcześniejszych, na dobre jednak rozwinęły się i ugruntowały w XX w., zwłaszcza po II wojnie światowej. Działania te, począwszy od lat 50. XX w., organizowane były nie tylko jako sporadyczne, przypadkowe wydarzenia, ale często jako planowe i zamierzone działania archiwów, mające na celu podnoszenie poziomu wiedzy społeczeństwa, jego poszczególnych grup i członków. Wraz z rozwojem samej działalności o podłożu kulturalno-oświatowym archiwa biorące udział w procesach kształceniowych - w edukacji pozaszkolnej, równoległej, zawodowej, ustawicznej, też nieformalnej i incydentalnej, zaczęły realizować zadania wynikające z funkcji edukacyjnej archiwów ${ }^{1}$. Zwłaszcza w ostatnich latach można zauważyć skok ilościowy i jakościowy inicjatyw edukacyjnych w archiwach ${ }^{2}$. Funkcja edukacyjna archiwów stawiana, zgodnie z typologią wyodrębnienia według celu działalności archiwum, tuż obok takich funkcji jak administracyjna czy naukowa, jest odpowiedzią archiwów na przemiany jakie zaszły i zachodzą we współczesnym świecie, społeczeństwie, kulturze ${ }^{3}$. Jest jedną z najpóźniej wyodrębnionych funkcji, jakie realizowane są obecnie w archiwach. Jest efektem naturalnych przemian, jakie dokonały i dokonują się w samych archiwach i ich otoczeniu, odpowiedzią na potrzeby tego otoczenia. Wraz z rozwojem funkcji i zadań z niej wynikających pojawiło się także zapotrzebowanie na dokształ-

1 Zob. A. Rosa, Funkcja edukacyjna archiwów, Warszawa 2012, s. 72-88.

${ }^{2}$ H. Mazur, A. Rosa, O potrzebie szkolenia archiwistów $w$ zakresie edukacji, „Archiwa - Kancelarie - Zbiory", nr 5 (7), 2014, s. 170-172.

${ }^{3}$ Zob. W. Chorążyczewski, Uwagi o przedmiocie i problematyce zantropologizowanej archiwistyki, [w:] Toruńskie konfrontacje archiwalne, t. 4: Nowa archiwistyka - archiwa i archiwistyka $w$ ponowoczesnym kontekście kulturowym, red. W. Chorążyczewski, W. Piasek, A. Rosa, Toruń 2014, s. 25-35; M. Jabłońska, W poszukiwaniu złotego środka. Kilka uwag na temat wewnętrznej i publicznej pracy archiwów, [w:] tamże, s. $151-161$. 
canie zawodowe archiwistów w tym kierunku i wyposażanie młodych adeptów zawodu w pożądane umiejętności i wiedzę4.

Prześledzenie zmian zachodzących w programach nauczania archiwistów na studiach wyższych, a także zmian w treściach realizowanych w czasie tych studiów przedmiotów, daje nie tylko ogólny ogląd na rozwój kształcenia archiwistów, ale również ukazuje przemiany, jakie w ostatnich dekadach zachodziły w archiwach oraz wymagania w zakresie wiedzy i umiejętności stawiane przed archiwistami.

W kształceniu archiwistów w Polsce po II wojnie światowej najpierw nacisk położono na umiejętności w zakresie odczytywania i rozumienia materiałów archiwalnych, następnie $\mathrm{w}$ centrum znalazły się umiejętności w zakresie porządkowania i opisywania zasobu, a także jego kształtowania i ogólnie selekcji archiwalnej. Następnie skupiono się na kompetencjach z zakresu informacji naukowej i informatyki, znajomości przepisów prawa, aż w końcu na tzw. kompetencjach miękkich, czyli np. umiejętności pracy z otoczeniem archiwum, w tym także podejmowanie działań popularyzatorskich czy edukacyjnych.

Dotychczas zadania wynikające $\mathrm{z}$ funkcji edukacyjnej realizowane były w polskich archiwach przez samych archiwistów/pracowników archiwów, choć można zaobserwować także sporadyczną współpracę w tym zakresie z edukatorami z innych instytucji, np. muzeów, ośrodków kultury, szkół. Osoby zajmujące się działalnością edukacyjną w archiwach podzielić można na dwie grupy. Do pierwszej zaliczyć osoby, które w czasie kształcenia i kariery zawodowej ukończyły lub brały udział w kursie pedagogicznym, pracowały w szkole lub innych placówkach oświatowych, pracowały w instytucjach kultury na stanowisku edukatora, animatora, pracownika kulturalno-oświatowego. Do drugiej grupy zaliczyć natomiast osoby, które doświadczenia lub przygotowania zawodowego w zakresie edukacji nie posiadały, zagadnienia te są im jednak bliskie i zazwyczaj sami dokształcają się w zakresie zagadnień edukacyjnych, biorąc udział w darmowych kursach, czytając fachową literaturę, obserwując działania edukatorów, również tych pracujących w innych placówkach kultury5.

${ }^{4}$ Zob. A. Rosa, Nowy profil $w$ zawodzie archiwisty - pedagog archiwalny, [w:] Nowe funkcje archiwów, red. I. Mamczak-Gadkowska, K. Stryjkowski, Poznań 2015, s. 133-139.

5 Zob. H. Mazur, A. Rosa, Manifest założycielski Forum Edukatorów Archiwalnych, http://edukacjaarchiwalna.pl/?page_id=28 (dostęp: 6 V 2016 r.); zob. też: H. Mazur, Niemiecka pedagogika archiwalna i polska edukacja muzealna - dwa wzorce dla dziaŁalności edukacyjnej archiwów państwowych w Polsce, [w:] Nowe funkcje archiwów, s. $141-156$. 
W praktyce archiwów w Polsce można stwierdzić, że ugruntowało się określenie na osobę zajmującą się edukacją w archiwach. Jest to edukator archiwalny, specjalistyczny profil w zawodzie archiwisty ${ }^{6}$. Jakie natomiast kompetencje, jaką wiedzę powinien on posiadać? Częściowo na te pytania odpowiada przygotowany przez Sekcję Edukacji Archiwalnej Stowarzyszenia Archiwistów Polskich i opublikowany w 2010 r. Model kompetencji zawodowych archiwisty $i$ zarzadcy dokumentacją

Przez kompetencje $\mathrm{w}$ modelu rozumiana jest suma wiadomości, umiejętności oraz postaw i zachowań, które pozwalają wykonywać zadania na określonym poziomie zawodowości. Model zawiera sylwetki i usystematyzowane wykazy kompetencji dla poziomów podstawowego i specjalistycznego. Przy czym dla poziomu specjalistycznego w dwóch zakresach, pierwszym dotyczącym dokumentacji powstałej do początku XX w. i drugim w zakresie promocji, edukacji i informacji archiwalnej.

W modelu kompetencje w zakresie promocji, edukacji i informacji archiwalnej zawierają następujące postulaty (celowo podkreślono te, które najbardziej odnoszą się do umiejętności i wiedzy edukatora archiwalnego), według których student:

- zna zasady i narzędzia promocji i autoprezentacji i potrafi je stosować dla budowy wizerunku archiwum,

- zna zasady i formy komunikacji społecznej i potrafi je wykorzystać dla poprawnego komunikowania się archiwum z otoczeniem oraz właściwej organizacji komunikacji interpersonalnej w obrębie archiwum,

- zna zasady i metody funkcjonowania e-administracji, rozumie rolę archiwów w ramach e-administracji,

- zna i rozumie zasady funkcjonowania społeczeństwa informacyjnego, rozumie rolę archiwów w społeczeństwie informacyjnym,

- zna zasady i metody psychologii i pedagogiki; potrafi stosować je w pracy z użytkownikiem materiałów archiwalnych i informacji archiwalnej,

- zna system oświatowy w swoim kraju i potrafi zaproponować formy udziału archiwów w procesie dydaktycznym,

${ }^{6}$ Zob. Forum Edukatorów Archiwalnych, http://edukacjaarchiwalna.pl/ (dostęp: 6 V 2016 r.).

7 Zob. Model kompetencji zawodowych archiwisty, http://sap.waw.pl/dzialalnosc statutowa/model-kompetencji-zawodowych-archiwisty (dostęp: 6 V 2016 r.). 
- zna i potrafi stosować formy działalności edukacyjnej skierowanej do różnych grup społecznych; jest otwarty na zapotrzebowanie edukacyjne społeczeństwa, potrafi je rozpoznać i na nie reagować,

- zna i umie stosować metody i narzędzia badania systemu informacji archiwalnej, a także jego melioracji,

- zna metody i problemy badawcze różnych nauk, aby przewidywać ich potrzeby informacyjne i planować działania zachęcające do wykorzystywania zasobu archiwalnego i wspomagające zachęconych użytkowników w pokonywaniu barier informacyjnych,

- zna i potrafi stosować metody badania potrzeb informacyjnych społeczeństwa, jego poszczególnych grup i jednostek.

Jaką zatem optymalną wiedzę w zakresie działalności edukacyjnej archiwów zgodnie z modelem kompetencji powinien posiadać absolwent studiów archiwistycznych? Warte podkreślenia jest to, że zgodnie z modelem kompetencje $\mathrm{w}$ zakresie edukacji traktowane są jako specjalistyczne, docelowo realizowane dopiero na studiach II stopnia. Natomiast kształcenie na poziomie podstawowym (czyli na studiach I stopnia lub studiach II stopnia, jeśli kształcenie w zakresie archiwistyki występuje jako specjalność na studiach historycznych) nie obejmuje treści z zakresu działalności edukacyjnej archiwów.

Absolwent studiów II stopnia w zakresie archiwistyki i zarządzania dokumentacją powinien umieć promować i popularyzować zasób archiwalny, wykorzystywać go do celów edukacyjnych i regionalnych. Powinien znać podstawy psychologii i pedagogiki oraz umieć je zastosować w pracy z otoczeniem archiwum. Ponadto powinien cechować się otwartością na zapotrzebowanie edukacyjne społeczeństwa, potrafić je rozpoznać i na nie reagować. Przewidywać potrzeby klientów archiwów i planować działania edukacyjne zachęcające do wykorzystywania zasobu archiwalnego i pomagające w pokonywaniu barier informacyjnych. Powinien znać system oświatowy, umieć nawiązywać współpracę z jego instytucjami, znać podstawy programowe kształcenia ogólnego i z nich korzystać w przygotowywaniu oferty edukacyjnej. Powinien znać formy udziału archiwów w procesie kształceniowym, a także metody dydaktyczne, umieć stosować je w odniesieniu do potrzeb i możliwości różnych grup społecznych, odbiorców działalności edukacyjnej archiwów. 
Zbiór kompetencji zawartych w modelu definiuje poniekąd profil edukatora archiwalnego, który w swojej pracy łączy wiedzę archiwisty z umiejętnościami pedagoga i animatora kulturowego. Z modelu wynika bowiem, że absolwent powinien znać podstawowe zagadnienia z zakresu psychologii i pedagogiki, aby umieć rozpoznawać i reagować na potrzeby edukacyjne zróżnicowanego społeczeństwa, dopasowywać do tych różnych osób i grup i ich potrzeb odpowiednie formy i metody, jednocześnie też znać system oświatowy i sposób jego funkcjonowania (programy itp.).

Model opublikowany w 2010 r. wpłynął na programy kształcenia uniwersyteckiego archiwistów zmieniane lub budowane na nowo w ciągu ostatnich pięciu lat (obecnie w Polsce jest już pięć ośrodków akademickich kształcących archiwistów w ramach osobnego kierunku studiów ${ }^{8}$ i kilkanaście ze specjalnością archiwistyczną), w tym także spowodował zmiany w programie kształcenia na istniejącym od 2006 r. toruńskim kierunku archiwistyka i zarzadzanie dokumentacją.

Kształcenie na poziomie akademickim w zakresie kompetencji dotyczących działań edukacyjnych czy też kulturalno-oświatowych/popularyzatorskich podejmowanych przez archiwa zaobserwować można na Uniwersytecie Mikołaja Kopernika już w okresie wcześniejszym, przed 2010 r.

W początkowym etapie kształcenia archiwistów na Uniwersytecie Mikołaja Kopernika w Toruniu (od 1951 r.) absolwent bardzo ogólną wiedzę na temat realizacji zadań archiwów związanych z popularyzacją zasobu miał możliwość zdobyć jedynie zazwyczaj w czasie programowych wycieczek do archiwów centralnych i terenowych oraz w czasie praktyk wakacyjnych w archiwach ${ }^{9}$, a także sporadycznie w ramach zajęć z metodyki archiwalnej ogólnej, obejmujących treści wynikające z wszystkich podstawowych funkcji archiwum, tj. gromadzenia, przechowywania, opracowywania i udostępniania materiałów archiwalnych (w ramach nauczania o udostępnianiu zazwyczaj realizowane były treści dotyczące ogólnych problemów udostępniania, informacji archiwalnej, organizacji i działania pracowni naukowej, bez omawia-

8 Są to: Uniwersytet Mikołaja Kopernika w Toruniu, Uniwersytet Marii Curie-Skłodowskiej w Lublinie, Katolicki Uniwersytet Lubelski, Uniwersytet Papieski Jana Pawła II w Krakowie, Uniwersytet Pedagogiczny im. Komisji Edukacji Narodowej w Krakowie.

9 Zob.: M. Friedberg, Przygotowanie do zawodu archiwisty, „Archeion”, t. 44, 1966, s. 22-29; F. Paprocki, Pięć lat studium archiwalnego w Toruniu, „Archeion”, t. 27, 1957, s. 315-318; A. Tomczak, Specjalizacja archiwalna $w$ Toruniu $w$ roku akademickim 1966/1967, „Archeion”, t. 49, 1968, s. 171-174. 
nia form związanych z popularyzacją zasobu) ${ }^{10}$, oraz $\mathrm{w}$ ramach zajęć dotyczących regionalistyki ${ }^{11}$. Zaznaczyć jednak należy, że w tym czasie studenci specjalności archiwalnej na UMK (do 1967 r.) ${ }^{12}$ zobowiązani byli do realizacji niemalże całego programu studiów obowiązującego na kierunku historia, w tym także przedmiotów pedagogicznych. Tym samym absolwenci specjalizacji otrzymywali jednocześnie podwójne kwalifikacje: archiwistów i nauczycieli historii ${ }^{13}$, byli zatem przygotowani do podejmowania w archiwum działań określanych wówczas jako kulturalno-oświatowe lub popularyzatorskie, do pracy z uczniami i instytucjami oświaty. W zasadzie żadnych nowości w zakresie wyposażania absolwentów specjalności archiwalnej w umiejętności dotyczące działalności popularyzatorskiej nie przyniosły zmiany w programach studiów wymuszone przez reformę studiów uniwersyteckich w latach 70. XX w. (od roku akad. 1973/1974 wprowadzono czteroletni cykl nauczania w miejsce pięcioletniego i podział na specjalizacje: nauczycielską i archiwalną) $)^{14}$, z programu zniknął jednak przedmiot dotyczący problemów regionalistyki (15 godz.) ${ }^{15}$.

W 1973 r. uruchomiono na UMK Podyplomowe Studium Archiwistyki (PSA), początkowo tylko w zakresie kursu niższego przeznaczonego dla pracowników archiwów, którzy nie mają ukończonych studiów specjalistycznych w zakresie specjalizacji archiwalnej ${ }^{16}$. Od roku akad. 1976 w ramach PSA uruchomiono także tzw. kurs wyższy dla pracowników archiwów. Program kursu

10 I. Janosz-Biskupowa, Aktualny stan kształcenia archiwistów na uniwersytetach polskich, Toruń 1976, s. 6.

11 Zob.: A. Tomczak, Projekt programu uniwersyteckiego kierunku archiwistyki, [w:] Uniwersyteckie kształcenie archiwistów, Warszawa-Łódź 1978, s. 14-17; tenże, Kształcenie archiwistów w Polsce i niektórych innych krajach europejskich, Toruń 1976, s. 41.

12 B. Ryszewski, Specjalizacja archiwistyczna na Uniwersytecie Mikołaja Kopernika $w$ Toruniu i jej absolwenci $w$ latach 1951-1967, „Zeszyty Naukowe Uniwersytetu Mikołaja Kopernika”, Historia z. 5, 1969, s. 136.

13 Cyt. za tamże, s. 129.

14 Zob.: A. Tomczak, Specjalizacja archiwalna $w$ roku akademickim 1972/1973 na Uniwersytecie M. Kopernika w Toruniu, „Archeion”, t. 61, 1974, s. 340-341; tenże, Specjalizacja archiwalna na Uniwersytecie $M$. Kopernika $w$ Toruniu $w$ roku akademickim 1973/1974, „Archeion”, t. 64, 1976, s. 287-288.

15 Tenże, Kształcenie archiwistów $w$ Polsce i niektórych innych krajach europejskich, Toruń 1976, s. 41; W. Chorążyczewski, W. Kwiatkowska, Kształcenie archiwistów na Uniwersytecie Mikołaja Kopernika w Toruniu w latach 1951-2001, „Archiwista Polski”, 2001, nr 3-4, s. 59-65.

16 A. Tomczak, Specjalizacja archiwalna na Uniwersytecie M. Kopernika $w$ Toruniu w roku akademickim 1973/1974, s. 287. 
obejmował między innymi przedmiot archiwa jako ośrodki pracy regionalnej, w ramach którego poruszano zagadnienia dotyczące udziału archiwów w ruchu regionalnym i badaniach regionalnych ${ }^{17}$. Od 1978 r. kurs wyższy przybrał charakter kursu specjalistycznego, poświęconego wybranym zagadnieniom, zorganizowano kolejno cztery kursy o takim charakterze. W roku akad. 1981/1982 kurs specjalistyczny poświęcony był problemom naukowo-informacyjnej działalności archiwów. W ramach tego kursu zrealizowano zajęcia dotyczące potrzeb informacyjnych użytkowników informacji archiwalnej i metod ich badania ${ }^{18}$.

To także na Podyplomowym Studium Archiwistyki, którego program można było łatwo modyfikować, w zasadzie w każdym roku mógł mieć inny przebieg, wprowadzono w latach $90 . \mathrm{XX} \mathrm{w} . \mathrm{w}$ ramach kursu podstawowego przedmioty odpowiadające czterem funkcjom archiwów: kształtowaniu, przechowywaniu, opracowywaniu i udostępnianiu, jako osobne metodyki, co pozwoliło zdobywać studentom umiejętności, na których kształcenie w ramach innych przedmiotów brakowało dotychczas czasu ${ }^{19}$. Przedmioty te następnie od roku akad. 2003/2004 były realizowane w ramach programu na studiach dziennych historia na specjalności archiwistyka i zarządzanie dokumentacją. Sama metodyka udostępniania zasobu archiwalnego realizowana była w wymiarze 30 godz. na IV roku studiów. Studenci oprócz form tradycyjnego udostępniania $\mathrm{w}$ archiwum bezpośrednio i pośrednio, zapoznawani byli także z różnymi formami popularyzacji zasobu ${ }^{20}$.

Przedmiot metodyka udostępniania zasobu archiwalnego następnie znalazł się w programie nauczania na uruchomionym w roku akad. 2006/2007 nowym kierunku studiów na UMK - archiwistyka i zarządzanie dokumentacją, nadal w wymiarze 30 godz., ale już nie na IV a na III roku studiów. W ramach przedmiotu studenci poznawali formy popularyzacji zasobu, z naciskiem na wystawiennictwo archiwalne, a także metody badań potrzeb użytkowników archiwów. W ramach zajęć studenci odwiedzali także wystawy ar-

17 M. Gołembiowski, Specjalizacja archiwistyczna na Uniwersytecie Mikołaja Kopernika $w$ Toruniu $w$ roku akademickim 1976/1977, „Archeion”, t. 68, 1979, s. 336; M. Gołembiowski, H. Robótka, Dziesięć lat Studium Podyplomowego Archiwistyki w Toruniu (1973-1983), „Archeion”, t. 80, 1986, s. 297.

18 M. Gołembiowski, H. Robótka, dz. cyt., s. 298.

19 W. Chorążyczewski, W. Kwiatkowska, Powołanie specjalności „Archiwistyka i zarządzanie dokumentacją" na UMK w kontekście prac nad utworzeniem osobnego kierunku studiów, „Archeion”, t. 105, 2003, s. 66.

20 Tamże, s. 67-69. 
chiwalne organizowane przez toruńskie archiwa, a także w ramach realizacji programu studiów brali udział w obowiązkowym objeździe archiwów ${ }^{21}$.

Od roku akad. 2012/2013 na studiach I i II stopnia archiwistyka i zarządzanie dokumentacją obowiązuje nowy program studiów. Na studiach I stopnia nadal realizowany jest przedmiot metodyka udostępniania zasobu archiwalnego na III roku studiów, natomiast na studiach II stopnia pojawił się przedmiot praca publiczna archiwów (ostatni semestr studiów, II rok II stopnia). W ramach nowego przedmiotu studenci osiągają następujące efekty kształcenia:

- student ma pogłębioną prowadzącą do specjalizacji wiedzę na temat udostępniania zasobu archiwalnego;

- ma pogłębioną, prowadzącą do specjalizacji wiedzę z zakresu prowadzenia działalności informacyjnej przy użyciu nowoczesnych technologii informacyjnych;

- ma pogłębioną wiedzę o archiwach i instytucjach kultury, zna ich specyfikę i różnice w zarządzaniu nimi;

- zna otoczenie archiwów i innych instytucji dokumentacyjnych, orientuje się w życiu kulturalnym i naukowym swojego kraju, zna możliwości i formy udziału tych instytucji w planowanych lub realizowanych projektach;

- ma pogłębioną wiedzę o człowieku jako twórcy i użytkowniku informacji, zasobów informacyjnych oraz systemów informacyjnych;

- zna zasady, możliwości i źródła finansowania działalności archiwalnej;

- zna podstawowe zasady i metody pedagogiki;

- zna system oświatowy w swoim kraju;

- zna formy działalności edukacyjnej skierowanej do różnych grup społecznych;

- potrafi porozumiewać się z wykorzystaniem różnych kanałów i technik komunikacyjnych ze specjalistami w zakresie archiwistyki oraz niespecjalistami, a także popularyzować wiedzę o narodowym zasobie archiwalnych oraz instytucjach go wytwarzających i przechowujących;

- potrafi stosować podstawowe zasady i metody pedagogiki w pracy z użytkownikiem materiałów archiwalnych i informacji archiwalnej;

- potrafi zaproponować formy udziału archiwów w procesie dydaktycznym;

21 Zob. Sylabus przedmiotu metodyka udostępniania zasobu archiwalnego w roku akad. 2010/2011, https://usosweb.umk.pl/kontroler.php? action=katalog2/przedmioty/pokazPrzedmiot\&kod=1202-A-MUZA-S1 (dostęp: 20 VI 2016 r.). 
- potrafi stosować formy działalności edukacyjnej skierowanej do różnych grup społecznych;

- potrafi rozpoznać zapotrzebowania edukacyjne społeczeństwa i na nie reagować;

- aktywnie uczestniczy w działaniach na rzecz zachowania dziedzictwa kulturowego regionu i kraju poprzez udzielanie w obszarze życia zawodowego pomocy osobom i instytucjom życia publicznego oraz inspirowanie i organizowanie wszelkich przedsięwzięć w tym zakresie;

- aktywnie uczestniczy i interesuje się aktualnymi wydarzeniami i nowatorskimi wydarzeniami w sferze życia zawodowego, a szczególnie interesuje się aktualnymi wydarzeniami z życia archiwów, bibliotek, muzeów i innych instytucji kulturalnych;

- jest otwarty na zapotrzebowania edukacyjne społeczeństwa.

Zajęcia prowadzone są metodą projektu. Studenci pracują cały semestr w grupach, w ramach których opracowują projekt edukacyjny, tworząc scenariusze cyklu zajęć edukacyjnych dostosowanych do wybranej tematyki i grupy odbiorców: wystawę archiwalna, lekcję archiwalną, warsztaty, wycieczkę tematyczną, turystykę archiwalną, grę miejską. Przygotowując scenariusze zajęć, muszą określić czas i miejsce planowanych zajęć, grupę docelową, cel zajęć, metody realizacji, potrzebne środki, instytucje współpracujące, a także zastanowić się nad formami promocji wydarzeń.

W roku akademickim 2016/2017 w ramach studiów podyplomowych w zakresie archiwistyki i zarządzania dokumentacją na UMK uruchomione zostały nowe specjalizacje. Jedną z nich jest edukacja i promocja ${ }^{22}$, obejmująca cztery przedmioty specjalnościowe, dwa z zakresu promocji (komunikacja społeczna w archiwach, public relations w archiwach) i dwa z zakresu edukacji (pedagogika archiwalna ${ }^{23}$, formy działalności edukacyjnej archi-

${ }^{22}$ Dwie pozostałe specjalizacje to: archiwistyka kościelna i zarządzanie dokumentacją. Zob. O nas, http://www.spaizd.umk.pl/index.html (dostęp: 20 VI 2016 r.).

23 Zajęcia pedagogika archiwalna - ćwiczenia konwersatoryjne, 12 godz. zajęć dydaktycznych. Treści kształcenia: podstawowe pojęcia pedagogiki (w tym także cele, treści, metody, środki i formy organizacji procesów kształcenia); pedagogika archiwalna na świecie; profil specjalisty w zakresie działalności edukacyjnej archiwów; rozwój działalności oświatowej archiwów i udział archiwów w procesach kształcenia; organizowanie kształcenia w archiwum i przez archiwum; współpraca archiwum z systemem oświaty; cele, treści, metody, środki i formy kształcenia stosowane w toku działalności edukacyjnej archiwów; lekcja archiwalna i jej budowa; podstawa programowa kształcenia ogólnego. Efekty kształcenia - umiejętności i kompetencje: znajomość organizacji działalności kulturalno-oświatowej i edukacyjnej archiwów; 
wów $\left.{ }^{24}\right)$. Studia podyplomowe dedykowane są osobom, które chcą dokształcić się zawodowo, poszukują nowych umiejętności i wiedzy. Wspomniana specjalność natomiast skierowana jest do osób, które zajmują się lub chcą się zajmować w archiwum popularyzacją zasobu i działalnością edukacyjną, kontaktami z otoczeniem archiwum i chcą zdobyć nowe kompetencje.

Potrzeba kształcenia archiwistów w zakresie wyposażania w umiejętności pozwalające sprostać nowym zadaniom, jakie przed archiwami są stawiane, zauważana jest przez ośrodki kształcące archiwistów. Co ciekawe, sam rozwój funkcji edukacyjnej archiwów w Polsce możliwy jest do prześledzenia również na podstawie tego, ile treści z zakresu tej sfery dzielności archiwów pojawiało się w kształceniu uniwersyteckim w ramach kolejnych zmian programowych. Potrzeba przygotowania archiwistów/pracowników archiwów do realizacji zadań wynikających z działań edukacyjnych podejmowanych przez archiwa czy też funkcji edukacyjnej archiwów długo nie była wyrażana, a w związku z tym także dostrzegana, zarówno w środowisku archiwalnym, jak i uni-

umiejętność dostosowywania odpowiednich celów, treści, metod, środków i form edukacyjnych w toku realizacji funkcji edukacyjnej archiwów; wyposażenie w wiedzę o skuteczności różnego rodzaju zabiegów dydaktyczno-wychowawczych; umiejętność badania i reagowania na potrzeby środowiska oświatowego; umiejętność stworzenia scenariusza lekcji archiwalnej; umiejętność korzystania z podstaw programowych kształcenia ogólnego.

${ }^{24}$ Zajęcia formy działalności edukacyjnej archiwów - ćwiczenia konwersatoryjne, 12 godz. zajęć dydaktycznych. Treści kształcenia: przegląd, analiza i typologia form dz. edukacyjnej archiwów; archiwalne pomoce edukacyjne i sposoby ich opracowywania; badanie potrzeb użytkowników i planowanie działalności edukacyjnej archiwów pod kątem ich zaspokojenia; przegląd i krytyczne omówienie wystawiennictwa archiwalnego w Polsce; budowa i rodzaje wystaw archiwalnych; scenariusze form działalności edukacyjnej archiwów, np. warsztatów, turystyki archiwalnej, gier miejskich. Efekty kształcenia - umiejętności i kompetencje: umiejętność planowania działalności edukacyjnej archiwów dostosowanej do rozpoznanych potrzeb użytkowników; umiejętność przeprowadzenia konkretnego działania edukacyjnego w scharakteryzowanym zakresie; umiejętność stosowania i dostosowywania odpowiednich form, metod i technik kształcenia do możliwości percepcyjnych odbiorców działalności edukacyjnej archiwów; umiejętność przeprowadzania zajęć edukacyjnych w oparciu o formy i metody kształcenia; znajomość i umiejętność tworzenia archiwalnych pomocy edukacyjnych; umiejętność poprawnego budowania wystaw archiwalnych (umiejętność budowania katalogu wystawy archiwalnej; wiedza z zakresu metodyki eksponowania materiałów archiwalnych: warunki eksponowania - odpowiednia temperatura, wilgotność względna, oświetlenie, gabloty wystawowe, oryginały czy kopie na wystawach; umiejętność sporządzania napisów informacyjnych przy aktach i tzw. „tekstów wiążących" wystawę w całość); umiejętność poprawnego budowania innych form dz. edukacyjnej archiwów - np. warsztatów, turystyki archiwalnej, gier miejskich. 
wersyteckim. Zagadnienia z zakresu edukacji archiwalnej nie podejmowane były też zbyt często $\mathrm{w}$ literaturze. Wraz z zmieniającymi się oczekiwaniami społeczeństwa wobec archiwów, a w związku z tym także zmianami w archiwach i potrzebami samych archiwistów zajmujących się działalnością popularyzatorską czy edukacyjną w zakresie posiadanych umiejętności, brak szkoleń i przygotowania zawodowego, które pozwalałyby na profesjonalne przygotowanie oferty edukacyjnej, zaczął być zauważany ${ }^{25}$.

Działalność edukacyjna archiwów, której rozwój trwa, przechodziła przez różne etapy, od przypadkowego i jednostkowego, często efemerycznego podejmowania działań edukacyjnych, po planowe i profesjonalne działania edukacyjne archiwów. Obecnie jest na etapie poszukiwania profesjonalnych rozwiązań, również tych dotyczących samego przygotowania zawodowego archiwistów do realizacji zadań wynikających z funkcji edukacyjnej archiwów.

Rozwój archiwów, kierunek zmian dotyczących zadań i realizacji tych zadań jakie przed nimi są stawiane, wynika z przemian w myśleniu o archiwach i ich istocie przez samych archiwistów, pracowników archiwów, opiekunów archiwaliów, to archiwiści są spiritus moventes zmian zachodzących w archiwach, to archiwiści sami określają miejsce i role archiwów w zmieniającym się społeczeństwie i swoimi działaniami te postulaty realizują, często bez względu na system polityczny i prawny, w jakim przychodzi im funkcjonować. To sami archiwiści dostrzegli z jednej strony potencjał edukacyjny tkwiący $\mathrm{w}$ archiwach i ich zasobach, z drugiej potrzebę podejmowania przez archiwa działań edukacyjnych, włączania się w procesy edukacji, edukowania swoich użytkowników ${ }^{26}$. Ten fakt podkreślał już w podręczniku Metodyka pracy archiwalnej Stanisław Nawrocki, podając, iż organizowanie spotkań informacyjnych w archiwach z przedstawicielami różnych środowisk było rezultatem inicjatywy archiwistów, do 1976 r. nie ukazały się bowiem żadne zarządzenia w tej sprawie $^{27}$, a przecież działania te były realizowane już w okresie wcześniejszym.

${ }_{25}$ Zob. np.: A. Cieślak, Edukacyjne funkcje archiwów - trudna misja $w$ trudnej rzeczywistości, [w:] Archiwa w nowoczesnym społeczeństwie. Pamiętnik V Powszechnego Zjazdu Archiwistów Polskich, Olsztyn 6-8 września 2007 r., red. J. Porazinski, K. Stryjkowski, Warszawa 2008, s. 105-108; W. Chorążyczewski, Archiwista przyszłości - edukator i autopromotor $w$ społeczeństwie informacyjnym, [w:] tamże, s. 45-53.

26 Zob. H. Mazur, W obronie edukacji $w$ archiwach. Kilka uwag i refleksji na marginesie artykułu Pawła Guta „O miejsce archiwów państwowych $w$ badaniach nad historia regionu”, „Archiwista Polski”, 2013, nr 2, s. 49-62.

27 Dopiero pismo okólne Naczelnego Dyrektora Archiwów Państwowych z 15 grudnia 1976 r. w sprawie obowiązków pracowników informacji zalecało organizowanie 


\section{Literatura}

Chorążyczewski W., Archiwista przyszłości - edukator i autopromotor $w$ społeczeństwie informacyjnym, [w:] Archiwa w nowoczesnym społeczeństwie. Pamiętnik V Powszechnego Zjazdu Archiwistów Polskich, Olsztyn 6-8 września 2007 r., red. J. Porazinski, K. Stryjkowski, Warszawa 2008.

Chorążyczewski W., Uwagi o przedmiocie i problematyce zantropologizowanej archiwistyki, [w:] Toruńskie konfrontacje archiwalne, t. 4: Nowa archiwistyka - archiwa $i$ archiwistyka $w$ ponowoczesnym kontekście kulturowym, red. W. Chorążyczewski, W. Piasek, A. Rosa, Toruń 2014.

Chorążyczewski W., Kwiatkowska W., Kształcenie archiwistów na Uniwersytecie Mikołaja Kopernika w Toruniu w latach 1951-2001, „Archiwista Polski”, 2001, nr 3-4.

Chorążyczewski W., Kwiatkowska W., Powołanie specjalności „Archiwistyka i zarządzanie dokumentacją" na UMK $w$ kontekście prac nad utworzeniem osobnego kierunku studiów, „Archeion”, t. 105, 2003.

Cieślak A., Edukacyjne funkcje archiwów - trudna misja $w$ trudnej rzeczywistości, [w:] Archiwa w nowoczesnym społeczeństwie. Pamiętnik V Powszechnego Zjazdu Archiwistów Polskich, Olsztyn 6-8 września 2007 r., red. J. Porazinski, K. Stryjkowski, Warszawa 2008.

Forum Edukatorów Archiwalnych, http://edukacjaarchiwalna.pl/ (dostęp: 6 V 2016 r.).

Friedberg M., Przygotowanie do zawodu archiwisty, „Archeion”, t. 44, 1966.

Gołembiowski M., Robótka H., Dziesięć lat Studium Podyplomowego Archiwistyki w Toruniu (1973-1983), „Archeion”, t. 80, 1986.

Gołembiowski M., Specjalizacja archiwistyczna na Uniwersytecie Mikołaja Kopernika $w$ Toruniu $w$ roku akademickim 1976/1977, „Archeion”, t. 68, 1979.

Jabłońska M., W poszukiwaniu złotego środka. Kilka uwag na temat wewnętrznej i publicznej pracy archiwów, [w:] Toruńskie konfrontacje archiwalne, t. 4: Nowa archiwistyka - archiwa $i$ archiwistyka $w$ ponowoczesnym kontekście kulturowym, red. W. Chorążyczewski, W. Piasek, A. Rosa, Toruń 2014.

Janosz-Biskupowa I., Aktualny stan kształcenia archiwistów na uniwersytetach polskich, Toruń 1976.

Mazur H., Niemiecka pedagogika archiwalna i polska edukacja muzealna - dwa wzorce dla działalności edukacyjnej archiwów państwowych w Polsce, [w:] Nowe funkcje archiwów, red. I. Mamczak-Gadkowska, K. Stryjkowski, Poznań 2015.

Mazur H., Rosa A., Manifest założycielski Forum Edukatorów Archiwalnych, http://edukacjaarchiwalna.pl/?page_id=28 (dostęp 6 V 2016 r.)

Mazur H., Rosa A., O potrzebie szkolenia archiwistów $w$ zakresie edukacji, „Archiwa Kancelarie - Zbiory", nr 5 (7), 2014.

spotkań informacyjnych z przedstawicielami gospodarki, cyt. za: S. Nawrocki, Udostępnianie akt, [w:] Metodyka pracy archiwalnej, red. S. Nawrocki, S. Sierpowski, Poznań 1992, s. 200. 
Mazur H., W obronie edukacji $w$ archiwach. Kilka uwag i refleksji na marginesie artykułu Pawła Guta „O miejsce archiwów państwowych w badaniach nad historią regionu”, „Archiwista Polski”, 2013, nr 2.

Model kompetencji zawodowych archiwisty, http://sap.waw.pl/dzialalnosc_statutowa/ model-kompetencji-zawodowych-archiwisty (dostęp: 6 V 2016 r.).

Nawrocki S., Udostępnianie akt, [w:] Metodyka pracy archiwalnej, red. S. Nawrocki, S. Sierpowski, Poznań 1992.

Paprocki F., Pięć lat studium archiwalnego w Toruniu, „Archeion”, t. 27, 1957.

Rosa A., Funkcja edukacyjna archiwów, Warszawa 2012.

Rosa A., Nowy profil w zawodzie archiwisty - pedagog archiwalny, [w:] Nowe funkcje archiwów, red. I. Mamczak-Gadkowska, K. Stryjkowski, Poznań 2015.

Ryszewski B., Specjalizacja archiwistyczna na Uniwersytecie Mikołaja Kopernika w Toruniu i jej absolwenci $w$ latach 1951-1967, „Zeszyty Naukowe Uniwersytetu Mikołaja Kopernika", Historia, z. 5, 1969.

Tomczak A., Kształcenie archiwistów w Polsce i niektórych innych krajach europejskich, Toruń 1976.

Tomczak A., Projekt programu uniwersyteckiego kierunku archiwistyki, [w:] Uniwersyteckie kształcenie archiwistów, Warszawa-Łódź 1978.

Tomczak A., Specjalizacja archiwalna na Uniwersytecie M. Kopernika $w$ Toruniu $w$ roku akademickim 1973/1974, „Archeion”, t. 64, 1976.

Tomczak A., Specjalizacja archiwalna $w$ roku akademickim 1972/1973 na Uniwersytecie M. Kopernika w Toruniu, „Archeion”, t. 61, 1974.

Tomczak A., Specjalizacja archiwalna $w$ Toruniu $w$ roku akademickim 1966/1967, „Archeion", t. 49, 1968.

\section{Summary}

Educational activity of archives in archival training at the Nicolaus Copernicus University The article comprises two parts. The first one pays attention to educational function of archives and professional profile of a person, who would conduct such activity, which is an archival educator. It is shown that professional competences of the archival educator were determined in the paper of Archival Education Section of the Society of Polish Archivists, published in 2010, entitled "The model of professional competences of archivists and records managers", in its part concerning the professional level in promotion, education and archival information. The second part of the article describes training of archivists at the Nicolaus Copernicus University in Torun in the scope of content and skills connected with promotional, cultural and educational activity of archives in the past, the present and the future. 